\title{
中枢性めまいにおける平衡障害
}

\author{
小野泰三郎・飯田順・岩沢寛・中島 博昭 \\ 高橋 蘐子・岡田 智幸・佐藤 成樹
}

\section{Equilibrium Disorder in Patients with Dizziness of Central Lesions}

\author{
Yasusaburo Ono, Jun Iida, Hiroshi Iwasawa, \\ Hiroaki Nakashima, Kaoruko Takahashi, \\ Tomoyuki Okada and Shigeki Sato
}

(St. Marianna University School of Medicine)

We reported two patients with vertigo of central origin. Case 1 was a 68-yearold male who complained of right shoulder pain, bilateral tinnitus and right facial palsy. He was initially suspected of having an acoustic tumor, but was later found to have a tumor at the cerebello-pontine angle by neurotological examination. Case 2 was a 54-year-old male who had a traffic accident 18 years earlier. He complained of headache, dizziness, cochlear symptoms and transient unconsciousness. This case was diagnosed as the vertibulo-basilar insufficiency with post-traumatic lesions on the basis of neurotological examination, including tests of nystagmus and OKN.

These two cases indicate the importance of neurotological examination in patients with vertigo of central origin.

Key words: vertigo of central origin, neurotological examination, cerebello-pontine angle tumor, vertibulo basilar insufficiency

\section{はじめに}

近年，日常臨床においてめまい患者に増加の 傾向がみられ，とくに高秢化社会にともなら老 人に打忷るめまい症の増加，交通事故や転倒・ 外傷等の後遺症としてのめまい症の増加してい るのが現状のよらである.

周知のごとく体平衡は深部知覚, 視覚, 内耳 前庭からの input に始まる。これら各感覚器 の末端よりの input は中枢に㧧いて互に複雑
に連繋を保ち, 再び out put として送り出さ れ, それぞれ深部知覚運動系, 眼運動系として の機能を発揮し, 重力に対して平衡を維持して いる。しかしながら内耳前庭は感覚受容器とし ての機能に止まるため，障害が中枢に存在する 場合その影響は直接末梢前庭系には伝わり難 い.また一方末梢前庭系の障害では当然中枢神 経系の障害が認められず，眼運動系の障害に際 してみられるよらな特徴ある眼振を示さない。

聖マリアンナ医科大学耳鼻咽喉科学教室 
これらの基本的特徴を基としてめまい外来では 一般にめまい症を中枢性と末梢性に大別し，診 断の第一歩としている。しかし夹際の臨床にお いては問診時の訴えと検査所見の不一致，眼振 所見の不明確なこと，検査所見の多様性等の理 由から診断がつけ難く，原因不明のめまいとし て取扱かわれているものも少なくない。これら の症例に共通することは，1）問診の的磼・慎重 さに欠けること，2)めまい発症時と検查時期の 甚だしい時間的なずれ，3)症例によっては訴え と検查所見の不一致, または中枢障害, 末梢障 害共通の異常所見を示すことなどがあげられ， これが診断の複雑性を助長し, 原因不明として の条件となっていることが多い.

\section{問診について}

近年のごとく複雑多様化した社会生活に抢い ては個々をとり巻く社会生活に順応し難く，こ の結果人間の健康に必要な社会的外部環境と個 体との相互関係に破綻をもたらし，身体の適応 機能の低下を来すものも少なくないため, 社会 生活に必要な生理的刺激に対しても異常な反応 を示すことが考えられる，めまいといら症状は 前述した各感覚器に対する刺激が生理的範囲内 であるにも拘らず, 正常人では感じない回転感, 浮動感, 不安定感や立ちくらみについての表現 である，前庭系にお括ける障害の種類，部位，籁 囲および障害の発展経過により患者の訴へは多 彩となり得よう。したがって問診にあたっては 日常の生活状態またはその恋化による身体的, 精神的変動の有無をも聴取し, めまい発症との 関連性を考慮することもまた必要であろう。

めまい患者の訴えのらち，中枢障害を示唆す るものとして，1）めまいは一部血管障害を除き 一般に非回転性で, 激しいめまい発作や蝸牛症 状，自律神経症状を欠き，眼前暗黑感や立ちく らみをともならことが多い，2）それに比し平衡 障害が自他覚的に著明で, 歩行中の偏倚や階段 昇降時の不安感, 履物に対する不安定感等を訴 えることが多い，3）その他頭痛, 複視, 顔面知 覚や味覚の異常, 䛊嚥, 嗄声, 構音障害, 身幹
表 | 中枢性めまいの特徵（問診）

1. めまいは一般に浮動性で, 眼前隌黒感, 立ち くらみ，時に意識障害を伴らが，耳鳴，難聴 は少ない。

2. めまいは頭位，体位に影響されず，持続的.

3. めまいの自覚に比し, 平衡障害は著明.

4. 回転性めまいを伴うものは脳血管障害, Bruns 症候群，めまい性てんかん等.

5. その他, 頭痛, シビレ, 知覚, 運動障害等な んらかの神経症状を伴ら。

6. 未梢障菁ではめまい発作が主役であるが中枢 障害では神経症状が主役で，めまいはむしろ 随伴的である.

・四肢の知覚及び運動障害などの神経障害を伴 ならことが末梢障害との相異点としてあげられ る。すなわち末梢障害ではめまい発作とそれに 伴なら螖牛症状, 自律神経症状が著明であるに 反し，中枢障害では他覚的平衡障害が著明で， 自覚的な蝸牛症状, 前庭症状が軽徽な特性を示 す（表 1).

\section{検査時期について}

めまい症に括ける診断過程の複雑性は問診時 における患者の言語およびその内容, 動作など 外見的状態と疾患の本質とが必ずしも一致し ないことにより旮められる。めいについての 表現は常に純粋に障害による身体的苦痛を的確 に訴えるものとは限らず，主推見と心理学的条件 （精神的動摇，不安）が加わり，修飾された訴 えとなり易い，めまい外来に打いてある程度の 経験を経れば患者の状態を钼察しながら問診す ることにより，障害が中枢か未梢かの大別はほ ぼつく症例が多いが，問診時の訴えはあくまで も患者の主観であり，われわれはこれを他覚的 に定性，定量化して客観的な診断の 裏付けと し，ょり正確な診断の資料としなければならな い. 障害とその表現掞よびこれに対する他覚的 診断の三者を結び，めまいの本質を見究めるの が検查の目的である. 機能的または器質的障害 も身体の一部として生物学的過程にしたがい進 
展または消退してゆく。したがって検查はその 時宜に応じて必要限度に実施されるのが望まし い. 検查のため数カ月以上も待たされる症例も 稀ではないが，原因不明とされる大きな理由の 一つと言えよう。

主要な前庭反射のらち感覚受容器であると同 時に運動機能を有する眼球は，それ自体障害に 応じた反応を正確に表現する，脊䯣反射が中枢 障害と末梢障害において性質上有意差を示し， 診断的価值を示すことは言うまでもないが，近 年眼球運動の異常と中枢障害に括ける病巣の局 在診断が次第に解明され, 眼振钼察の診断価值 が特に強調されている。しかし中枢障害では隣
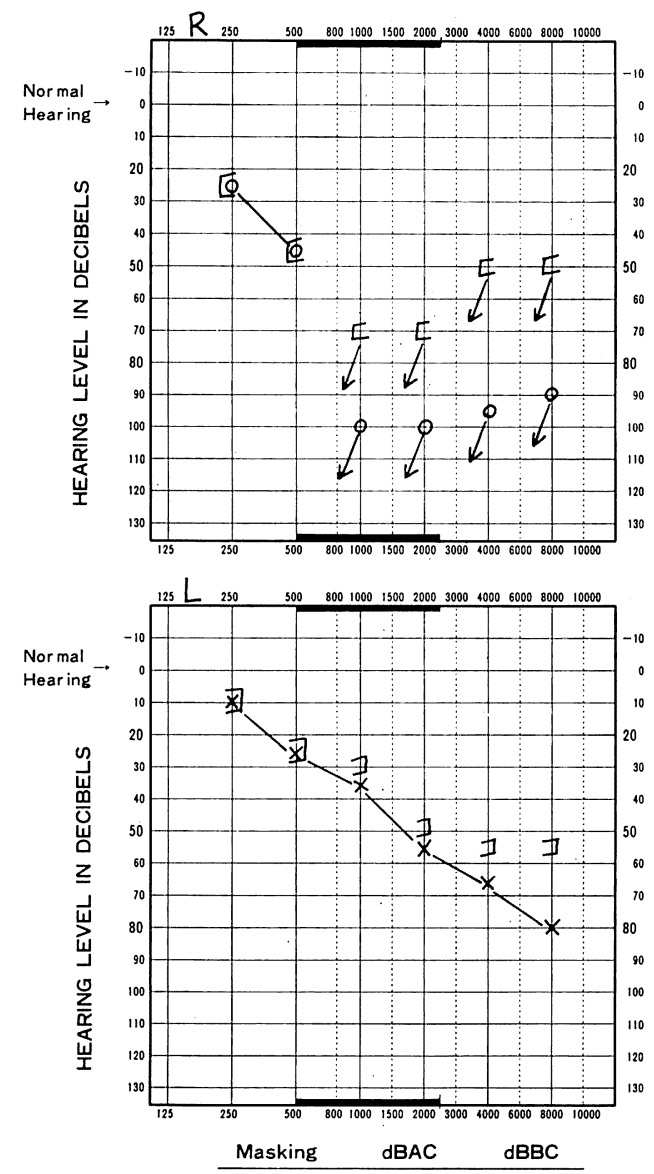

図 I 症例 1
接する神経線維や諸核との連慗が多く，単一特 徵的な眼振よりも複雑な眼振所見をみることが 多いのも事実である。これらの理由から中枢障 害では各種の神経学的検査，X線検査，さらに は angiography やCT Scan 等の総合判定を 要することもある.

\section{症例}

つぎにわれわれが中枢性めまいとして取扱っ た 2 例を提示し参考に供したい。一例は聴神経 腫痬（AT）が疑われ，他の一他は脳循環不全 による中枢性めまいと思わ狆たものである.

症例 1 : 68才, 男性.

主訴：右肩痛，雨側耳鳴，難聴.

\section{症例 1 (平衛機能検查所見)}

立直り、㣂倚検查

立直り 不安定

家字右㣂倚

自発眼振（注視眼振）

頭位眼振
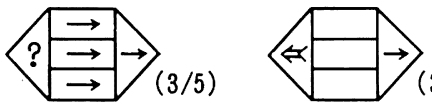

$(3 / 8)$

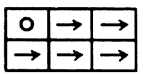

温度眼振

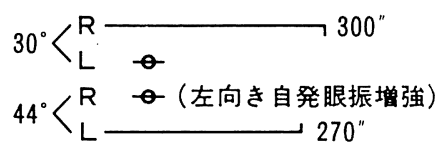

OKP 水平 垂直

軽度抑制

ETT

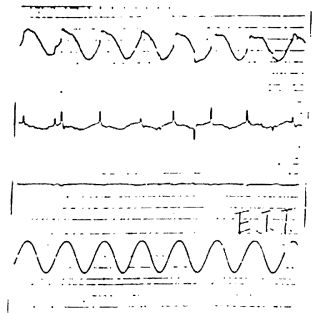

図 2 
現病歴：約半年前より急に立上った時にふら つきがあり，歩行中右へ偏倚し，階段を降りる 時上半身が不安定で，スリッパが履きにくくな った. 57年 1 月より右肩の痛み，右上肢のシビ レ感が強くなり, 針・炎治療により一時軽快す るも 2 月になり再度症状覀化し，3月 3 日脳外 科に歩行入院した.

家族歴，既往歴に特記すべきものなし.

入院時所見：右側眼瞼および口角に下垂を認 め, 第 $\mathrm{V}$ 神経第 2 枝の機能低下および右側味覚 に軽度の低下を示した。

\section{入院時診断：AT の疑い.}

神経耳科学的検査：聴力は雨侧感音難聴で, 右側 $1 \mathrm{kHz}$ 以上は scale out, ABR は雨側共反 応弱く, 右側は殆ど反応を示さない（図 1).

立直り検查：上下肢共に右へ偏倚し，全体とし て不安定. 自発・頭位眼振 : ENG 検查では左 向き方向固定性の眼振を認め, 経過中 Bruns 様 眼振を認めた。温度性眼振, 右向き眼振の抑制 と左向き眼振の延長がみられた。視運動性眼振 OKP は水平・垂直共に軽度の抑制, ETT は 軽度の断続性を示した（図 2 ）。

当科診断: 右側小脳橋角部腫渞.

小括：本症例は当初在 AT が疑われていた ものが神経耳科学的検討に上り, 右側小兴橋 角部腫瘍と考察されたものである。すなわち聴 力は右側に抢いて高度に障害された感音性難聴 を示したが，第VII神経はほぼ健在で，温度性眼 振も右側の反応を認め，また OKP 所見などか ら AT よりもむしろ CP angle の全般にわた る腫瘍性病変が疑われたものである。脳外科に 扎いても脳血管造影, CT scan 等により $\mathrm{CP}$ angle tumor と断定し, 後頭下開放術にて硬 脳膜を露出，透明な液に囲まれた cyste を認 め, その下に軟らかい腫瘍が小脳半球外側にて CP angleをほぼ充渾するように存在し，これ を除去した。

病理組織診断 : Meningioma.

症例 $2: 54$ 才, 男性.

主訴：めまい, 一過性意識障害.
現病歴：S40年 6 月交通事故後頭痛, 耳鳴, 難聴を伴らめまいが持続し，一過性の意識障害 をくり返していた５6年末よりめまいが增強 し，眼前暗黑感を伴ない，特に仰臥位で頭を右 上に向けた時症状が著明になる。

既往歴：18年前の交通事故の他特記すべきも のなし。

家族歴：特になし。

57 年 3 月脳外科入院, 頸部 X-P angio, CT scan にて C6-7 左側の Spur による椎骨動脈 のねじれを証明，同循環不全と診断された。

神経耳科学的検査：聴力は両側 $C^{5} \operatorname{dip}$ 型感 音難聴(図 3 )。立直り・書字検査共に右偏倚, 自発眼振左向，頭位眼振は方向交代性上向性眼 振を認めた。温度性眼振および視運動検査では 左右差または異常所見がみられなかった（図 $4)$.

以上の所見のうち, 聴力障害, 頭位眼振は中 枢障害を示唆するものであるが，上下肢の偏 倚, 自発眼振, OKNは中枢・末梢何孔とも判 定し難い所見である。頸性めまいではこのよう な何れとも判定し難い所見を示すことはしばし ばであるが，頭位を後属させ回転させたときに みられる眼振は椎骨動脈循環不全症を基盤とす る頸性めまいの特徴とされている ${ }^{1)}$. また一般 に無関係と考えられがちな古い交通事故をも考 え合せ，頭部外傷後遺症および椎骨脳底動脈循 環不全によるめまいと回答した。脳外科にて 前頸部より開放，C6〜7 椎間孔開放と C5 左横 突起前脚の下 $2 / 3$ を開放した。 術後 33 日目に第 2 回目の神経耳科学的検查を行なったが聴力の 恢復はみられず，足踏検査は左傾・右傾頭位で は術前より回転角の增加をみ，頭位眼振は不規 則性で方向交代性上向性眼振を認め，温度性眼 振は左 $\mathrm{CP}$ を示した。

小括 : 本症において問題となるのは血管のね じれと交通事故との因果関係である，交通事 故，血管のねじれ，めまいの三者に㧍ける関連 性を頸性めまいの発症機構から検討を加えた。 1955年, Ryan \& Cope $^{2)}$ は頸部がめまいの発 


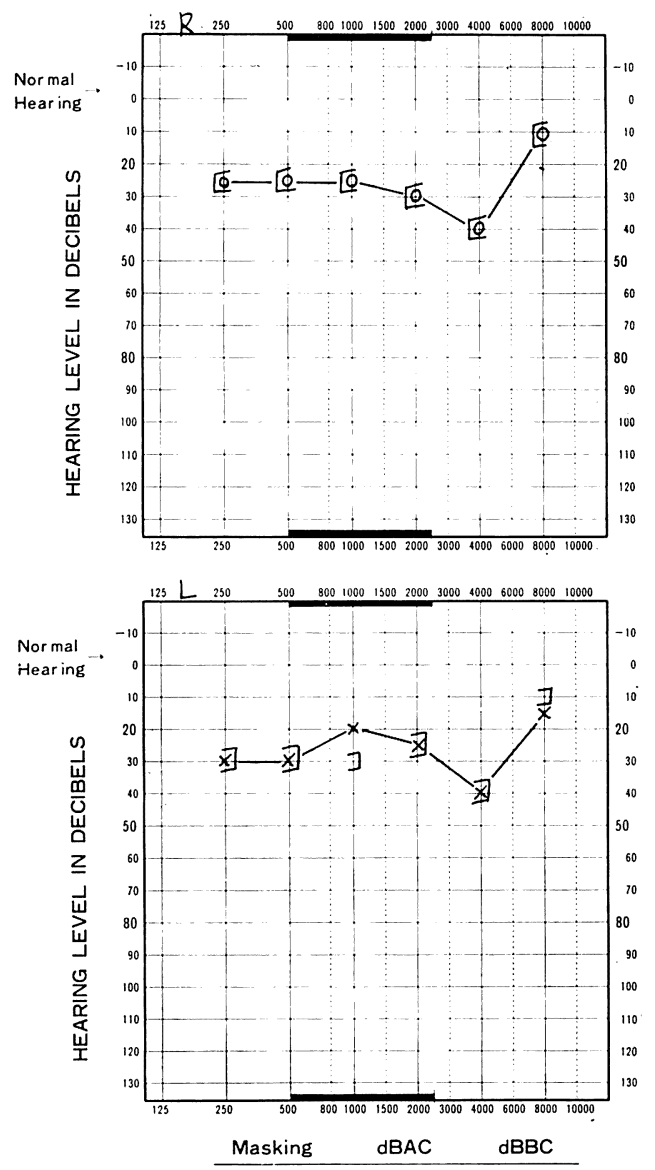

図 3 症例 2
生機構として大きな役彗を有することに着目 し, 頸部脊椎症によるめまい, 頸部隺引等法後 のめまい, 頸部外傷後のめまい, 合計 5 例につ いて検討を加え，めまいの発生機構として，1） 椎骨動脈の閉塞，2)頸部交感神経系の障害，3） 頸反射の障害をあげている（表 2 ），本症例の めまい発現は明らかに1)によるもので，脳底動 脈の循環障害はその流域下にある脳翰・小脳・ 後頭葉・前庭末梢器官の㴧を促し，一過性に 頭痛，めまい，耳鳴，意識障害，平衡障害を 起すとされている．本症例は受傷後間もなく発 症しているが，むち打ち症においては頸部軟部 組織の損傷による頸神経末梢刺激，C4～6 亿拉 ける椎間孔の神経根圧迫症状, あるいは血流障

症例 2 (平衡機能検査所見) 57.3.6.

$\begin{array}{rr}\text { 偏倚検查 } & \\ \text { 足踏 } & \text { 右偏倚 } \\ \text { 曺字 } & \text { 右偏倚 }\end{array}$

自発眼振

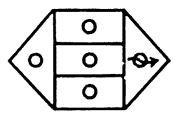

頭位眼振
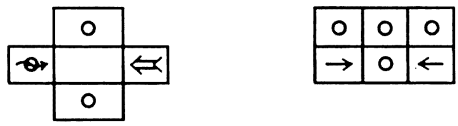

温度眼振

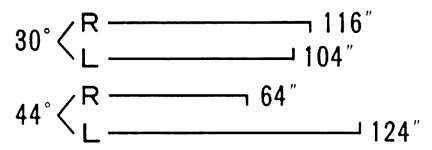

OKP 正常反応

図 4

表 2 頸性めまいの発現機蓝（Ryan, Cope)

1. 椎骨動挀の閉塞

2. 頸部交感神経系の障害

3 . 頸反射の障書

害による筋組織の酸素欠乏を来し，さらには頸 部の深部受容器よりの異常なインパルスが視床 下部一脳幹系，さらに小脳系の機能異常を恒常 化し, output として眼運動系, 脊䯣反射系に その異常が投射されることによりめまい, 平衡 障害を来すとされている. 本症例に沶ける血管 の異常は技とらく事故以前から存在し,さらに 事故による頸部深部受容器からの異常なインパ ルスと血管, 神経周囲の器質的障害とが相俟っ て急激な症状発現となったものと考えられる ${ }^{31}$. 術後の検查で改善を示さず，力向交代性上向性 眼振をみたのは，異常インパルスの恒常化を物 帒るものであるが，この様な症例には頸部牽引 療法, あるいは hot pack 等の物理療法や循環 
促進剤, 安定剂, 高単位ビタミン剂等が有効と されている.

神経耳科領域においては AT の診断は今日 さほど困難なものではないとされているが，中 には温度性眼振反射や聴力に殆ど異常を示さな いものや，症例 1 のごとく小脳橋角部腫瘍との 鑑別がつき難いものがあり，また症例 2 に拧 ける如く，中枢・末梢両障害の所見を示す頸性 めまいでは，特に古い交通事故についての問診 もまた重要な検査の一つであるときが痛感され る.

\section{高齢者のめまい}

最後に近年高齢者の増加に伴なら加齢による めまいの増加に注目したい.

高秢者のめまいのうち, 最も比率を占めるも の，一つに脳血管障害があげられる。そこで高 秢者のめまいと血圧との関連について考察を加 えた。

高路者に括ける動脈硬化は半ば生理的とも言 える障害で，脳動脈の血流障害は二次的に脳実 質の障害をもたらし，殆どの症例にめまいがみ られる。この様な脳動脈硬化症にみられるめま いその他の臨床症状は, 動脈の硬化の程度より はむしろそれに伴った脳循環障害によるものと されている，そして高血圧を伴った場合もとの 初期であれば細動脈硬化がなく, 細動脈硬化の 進行した患者ではしばしばめまいがみられると いら文。すなわち脳動脈硬化に高血圧を伴う場 合はめまいを起し易いが，細動脈硬化がなけ ればめまいをみることは少ない（表 3 ）。大友5) は剖検所見より脳の動脈硬化之密接な関連を有 する生前の臨床症状のらち，第一にめまいをあ げている。これらのめまいは一般に非回転性

表 3 高齢者の「めまい」と血圧との関係

\begin{tabular}{|c|c|c|}
\hline 器質的変化 & 誘 因 & 症 状 \\
\hline 脳動脈硬化症 ) & 血圧の低下 & \\
\hline 細動脈硬化症 $\}+$ & + 血圧の上昇 & \\
\hline 形態 異 常 & $\begin{array}{l}\text { 多 血 症 } \\
\text { 血液凝固性六追 }\end{array}$ & $\begin{array}{l}\text { (不全麻瘦 } \\
\quad \text { 運動失調) }\end{array}$ \\
\hline
\end{tabular}

で，急激な頭位，体位の変換や早朝起床時，ま たは前かがみになった時に扤こるものが多いよ らである。

これに反し低血圧はめまいを起し易く，血圧 下降に伴い一過性脸虚血症を起すものは現在脳 血行不全と呼ばれている，その本態は血圧低下 に伴ら副血行路の代償不全によるもので，血圧 恢復と共に症状が消失する ${ }^{6)}$. その好発部位は 内頸動脈, 椎骨脳底動脈といわれ，藤井は脳血 行不全を起すような人の脳，または頸部の動脈 に強い硬化を認めることが多いと述べている7 . いずれにしても高秢者のめまいは脳動脈硬化の 結果として血流の減少 -ischemia一 脳代謝障 害によりひき起され，しかも血圧の変動が大き く影響されることから急激な血圧の下降には充 分注意を要する。大友 ${ }^{8)}$ は高齢者のめまいでは まず椎骨脳底動脈循環不全を疑い，その性状， 出現の様式を詳しく聴取し血圧の態度をよく観 察し，本症の診断は臨床的に行なうべきである と述べている.

\section{まとめ}

以上中枢障害に打けるめまいについて症例を 提示し，併せて中枢性めまいを来すものとして 脳循環不全によるめまい発症を脳動脈硬化と血 圧との関係に扣いて述べた。

脳中枢, 特に脳幹・小脳は体平衡に関する各 感覚受容器の中枢としてこれを統禦・整理し， 各運動系に output として規則的な反射を送り 出す。しかしながら末梢内耳前庭は前述の如く 感覚受容器に止まるため, 中枢に障害があって もとれが直接影響を及ぼすための著明な变化は みられない，すなわち障害の部位が末梢か中枢 かによって，投射される反射の異なりが中枢性 めまいと末梢性めまいとの鑑別の大きな根拠と なり得る。

めまい症は一般外来に拈いて鬼角敬遠されが ちな疾患であり，さらにまた中枢性の平衡障害 は末梢性に比し高度であるにも拘らず，訴える めまい症状は軽徵であることから軽視され易い 傾向がみられる。しかも中枢障害の中には重大 
疾患も含まれ，これを見過ごす危険性も多分に ある.したがって正しい問診と眼振所見，神経 症状の有無, 経時的钼察を行ない, 耳科医は勿 論のこと他科に扔いてもさらに積極的な対応が 必要と思われる。

本論文の要旨は第38回日耳鼾学会神奈川地方部会シ ンポジウムにおいて発表した.

\section{参考文献}

1) Kornhuber $\mathrm{HH}$ : 神経耳科学 (坂田英治他訳). 医蒾薬出版, 1973.

2) Ryan GMS and Cope S: Cervical vertigo. Lancet 2: 1355 1358, 1955.
3) Laskiewicz A: Cervical spondylosis and the ear. Acta Otolaryngol 51 : 403 410, 1938.

4) 猪 初男: めまい. 95 99頁, 文京社, 1963.

5 ) 大友英一: 脳血管障害の臨床. 87 88頁, 中外医 学社, 1973.

6 ) 後藤文男 : 脳血管障圊の臨末. 93 94頁, 中外医 学社, 1973 .

7 ) 藤井 潤 : 脳血管障害の臨床. 94 95頁, 中外医 学社, 1973.

8) 大友英一 : 後頭蓋召血管障害. Medicina 14(5): 710 711頁, 医学畫院, 1977.

\footnotetext{
/ 別刷請求先 : 小野泰三郎

干213 川崎市宮前区菅生2-16-1

聖マリアンナ医科大学耳鼻咽喉科学教室
} 